\title{
Narzędzia Lean Management w procesie produkcji napełniaczy do poduszek powietrznych na przyktadzie firmy Daicel Safety Systems Europe Sp. z 0.0.
}

http://dx.doi.org/10.18778/8142-085-3.02

\author{
Magda Ślebioda, Pawet Rakowski \\ Koło Naukowe Młodych Logistyków „Just in Time” \\ Państwowa Wyższa Szkoła Zawodowa im. Angelusa Silesiusa w Wałbrzychu
}

\section{Wstęp}

Firma Daicel Safety Systems Europe Sp. z o.o., działająca głównie poza granicami Polski (Japonia, USA, Chiny, Tajlandia, Korea Południowa), zainspirowała studentów swoją działalnością w Polsce. Jedyny oddział tej firmy w Polsce znajduje się w Żarowie w województwie dolnośląskim. Daicel Safety Systems zajmuje się produkcją napełniaczy do poduszek powietrznych - a zatem wiążących się z odpowiedzialnością za ludzkie życie. Narzędzia Lean Management stosowane w procesie produkcyjnym to idealny przykład tego, jak firmy współcześnie działające na rynku rozwijają się i dbają o klienta. Zaczynając od systemu Poka-Yoke, którego zadaniem jest wykrycie wszelkiego rodzaju nieprawidłowości podczas operacji standardowej, czyli ustawienia maszyn i dobrania odpowiedniego komponentu, poprzez narzędzia Kaizen, stosowane w firmie od początku działalności, aż do cyklu Deminga, firma Daicel Safety Systems zastosowała narzędzia Lean Management w każdym dziale. Na bieżąco wprowadzane są usprawnienia w produkcji. Dla przykładu w roku 2010 firma miała tylko 4452 propozycje usprawnienia procesów, a już w roku 2014 było ich aż 16571. $\mathrm{Na}$ tym przykładzie widać, że firma cały czas się rozwija i doskonali. Okazało się również, że sposoby wykorzystywania narzędzi Lean Management w Daicel Safety Systems są zbieżne z pomysłami studentów na to, czego brakuje tej firmie, aby działała bardziej ekonomicznie. Praktyka pokazuje, że pomimo sprawnie funkcjonującego systemu zarządzania zawsze znajdą się nowe pomysły na to, jak efektywniej wykorzystywać zasoby. Przedsiębiorstwa stosujące własne kon- 
cepcje funkcjonowania, posiadające wypracowane metody i swoistą kulturę często popełniają błędy przy wdrażaniu nowinek w zarządzaniu, dlatego studenci postanowili przedstawić najprostsze we wdrożeniu rozwiązania, które mogą być rozwinięciem tych obecnie już stosowanych.

\section{Lean Management okiem studenta...}

Wiele firm działających na rynku światowym stosuje koncepcje szczupłego zarządzania Lean Management. Liczne grono zarówno praktyków, jak i teoretyków z branży logistycznej, produkcyjnej czy transportowej słyszało wielokrotnie w swojej karierze słowo Lean. Lecz czy wszyscy z nich rozumieli, o czym mowa? Czy wiedzieli, że chodzi o usprawnianie produkcji? W wieku XXI każde przedsiębiorstwo w mniejszym lub większym stopniu stosuje narzędzia Lean, czasem nawet o tym nie wiedząc. Zatem wyjaśnijmy dokładniej, czym jest Lean? Skąd się wzięło to określenie? Jakie narzędzia używane są w ramach Lean Management?

Przedsiębiorstwa nowo powstające na polskim rynku oraz te, które działają już od kilku czy kilkunastu lat, coraz częściej stosują nowe metody pracy i nakazy postępowania o obco brzmiących nazwach. Kierownicy powtarzają, że „zastosowany został Lean i jego narzędzia”. Czy rzeczywiście tak jest?

Wyrażenie Lean Management i wszystkie wyrażenia pochodne (Lean Manufacturing, Office, itp.) pojawiają się w każdej firmie - przedsiębiorstwach produkcyjnych, biurach czy szpitalach. Odpowiedzmy zatem na postawione wcześniej pytania.

\section{Co to jest Lean Management?}

Lean Management to koncepcja zarządzania przedsiębiorstwem, która zakłada dostosowywanie go do warunków gospodarowania panujących na rynku na drodze przekształceń organizacyjnych i funkcjonalnych. Jest to powolny i ciągly proces racjonalizacji całej organizacji oraz jej relacji $z$ otoczeniem poprzez wprowadzanie licznych zmian w zakresie działalności, w strukturze majątku oraz sposobach zarządzania, ale także w dziedzinie przygotowania zawodowego oraz kształtowania postaw pracowników; wysmuklanie, wyszczuplanie, odchudzanie przedsiębiorstwa (Lichtarski, 1997: 224). 
W literaturze wymieniane są następujące filary Lean:

- Określenie i tworzenie wartości dla klienta;

- Ciągłe doskonalenie procesu poprzez eliminowanie marnotrawstw (z definicji 7 marnotrawstw);

- Szacunek dla załogi, przejawiający się w postawie przywództwa kadry zarządzającej.

W praktyce codziennej Lean jest obserwacją pracy, systemów istniejących w firmie, operacji i zadawaniem pytania, co można zrobić z oferowanymi przez firmę produktami czy usługami, by jak najlepiej zaspokoić potrzeby i wymogi klienta oraz zapewnić dostatecznie szybką realizację przy zachowaniu odpowiedniej jakości produktu.

Lean wymaga wspierania pracowników firmy, aby stawali się profesjonalistami w obszarze wykonywanej przez siebie pracy oraz załogą zdolną do rozwiązywania problemów i ciągłego doskonalenia przedsiębiorstwa ${ }^{1}$.

\section{Profesjonaliści w stosowaniu Lean?}

Z chwilą przeniesienia koncepcji Lean do USA uwaga została skupiona na narzędziach, a dokładniej metodach, którymi posługiwali się japońscy zarządzający. Metody te to między innymi: Just in Time, Kanban, Jidoka, Andon, 5S, praca standaryzowana, zarządzanie wizualne, TPM, SMED. Obecnie dostrzeżono, że pomijany był ważny aspekt, mianowicie potrzeba zmiany podejścia zarządzających do pracowników. Podejście to nazywane jest „przywództwem Lean”.

\section{Lean źle rozumiany...}

Błędne rozumienie Lean polega na tym, że określany jest on jako system eliminowania marnotrawstw lub zmniejszania kosztów. Takie pojmowanie nie wyczerpuje wszystkich zalet Lean i jest pewnym uproszczeniem, niepokazującym całości systemu wypracowanego na przełomie wielu lat. Błędnie jest on też utożsamiany $\mathrm{z}$ audytami w firmach mającymi na celu kontrolę zachowania czystości w miejscu pracy czy sprawdzenie dostępności instrukcji lub wypełniania norm. Takie błędne rozumienie wynika w wielu przypadkach z niewłaściwej postawy zarządzających.

1 https:mfiles.pl/pl/index.pho/Lean_management [dostęp 8.05.2016]. 


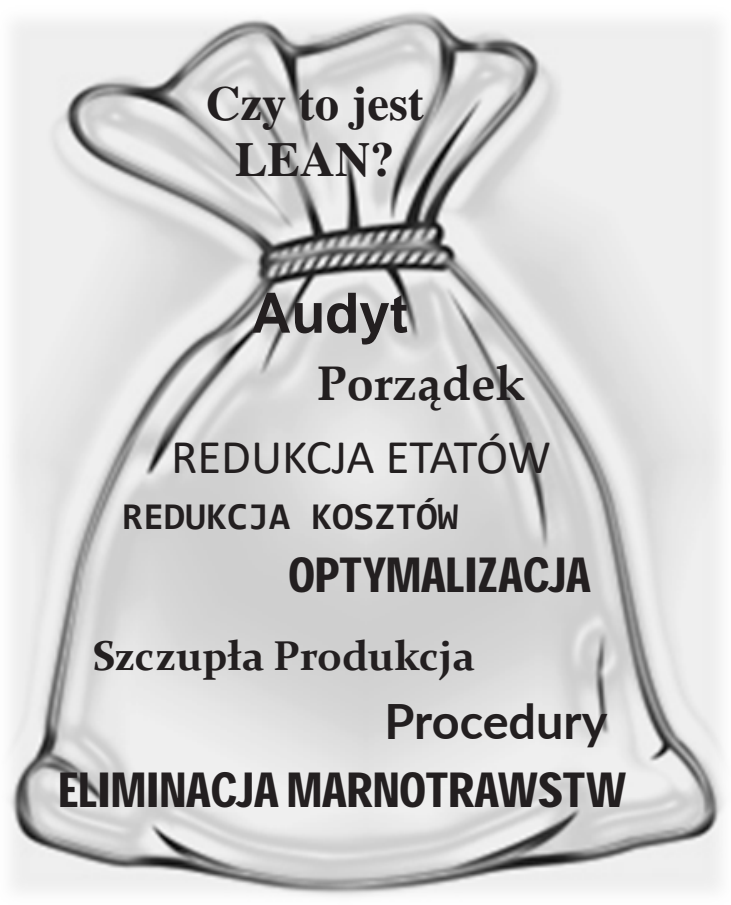

Rysunek 1. Elementy koncepcji Lean Management

Źródło: opracowanie własne na podstawie http://www.leancenter.pl/bazawiedzy/leanmanagement [dostęp 09.05.2016].

\section{Lean w procesie produkcji napetniaczy do poduszek powietrznych na przykładzie firmy Daicel Safety Systems Europe Sp. z 0.0.}

Firma Daicel Safety Systems Europe Sp. z o.o. (DSSE) należy do japońskiego koncernu Daicel Corporation Ltd. (DC), który powstał w 1919 r. Aktualnie firma wytwarza szeroką gamę wyrobów: produkty celuloidowe, produkty na bazie chemicznych substancji organicznych i plastiku, a także urządzenia pirotechniczne. Firma ta, wykorzystując swoją wiedzę i doświadczenie, wychodząc naprzeciw oczekiwaniom rynku w zakresie ochrony osób podróżujących samochodami, stworzyła lekkie, małe i przyjazne dla pasażera napełniacze do poduszek powietrznych. Specjalizacją zakładu jest produkcja napełniaczy do poduszek powietrznych dla kierowcy, pasażera, poduszek bocznych, kolanowych i kurtynowych. Podążając za 


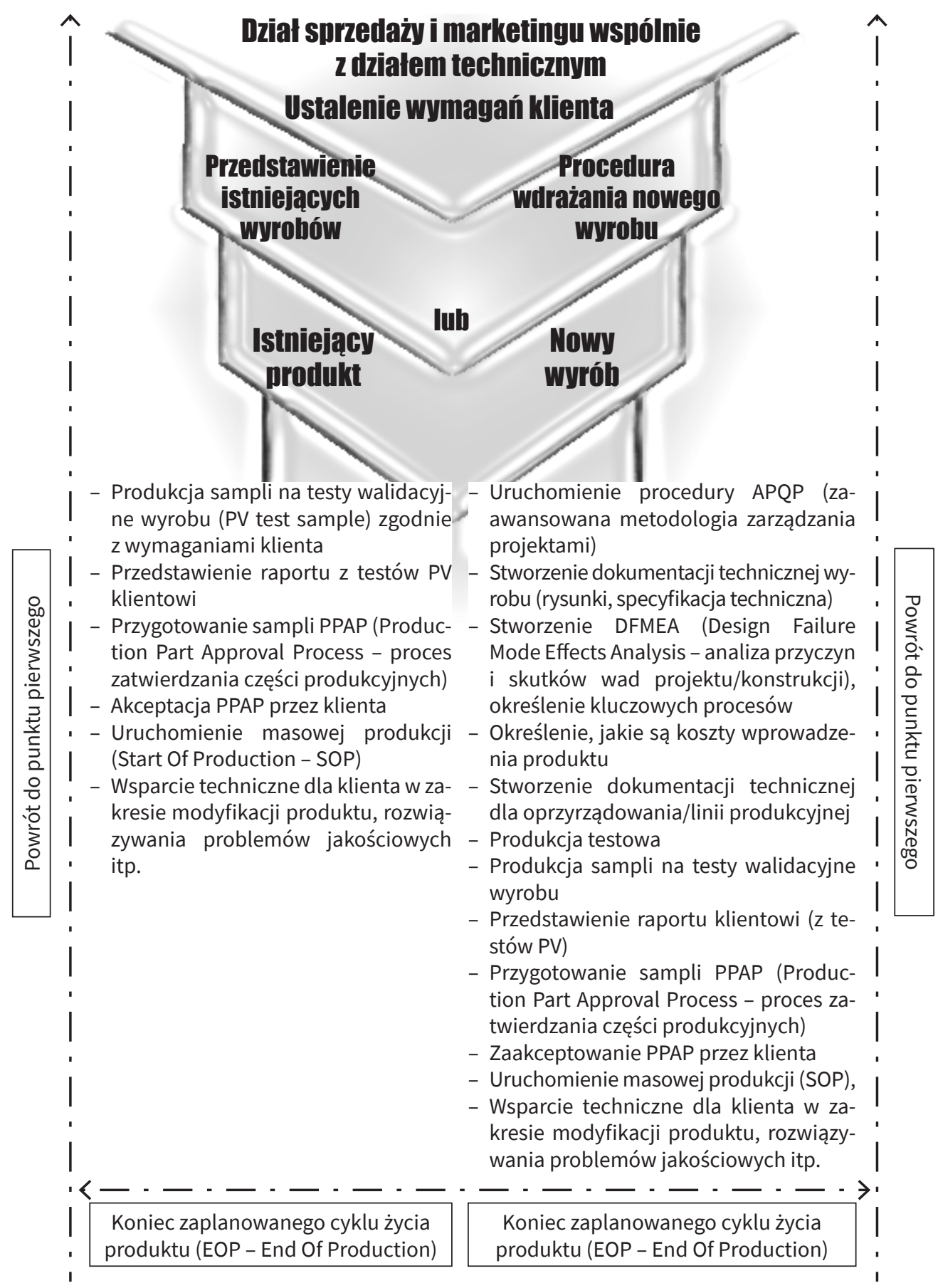

Rysunek 2. Cykl życia produktu w Daicel Safety Systems Europe Sp. z o.o.

Źródło: opracowanie własne na podstawie http://www.daicelsse.com/technologia,c11 [dostęp 10.05.2016]. 
wymaganiami rynku, DSSE wykorzystuje najnowocześniejsze technologie istniejące na rynku motoryzacyjnym w celu udoskonalenia i zmiany swoich produktów zgodnie z globalnymi trendami. Niebywałą zaletą Daicel Safety Systems jest również dążenie do miniaturyzacji oraz chęć tworzenia produktów przyjaznych środowisku poprzez eliminację szkodliwych substancji wyzwalających się podczas otwarcia poduszki powietrznej.

Wszystkie maszyny w DSSE wyposażone są w system Poka-Yoke, którego zadaniem jest wykrycie wszelkiego rodzaju błędów lub nieprawidłowości podczas wykonywania operacji. W przypadku np. umieszczenia w maszynie niewłaściwego komponentu maszyna nie rozpocznie pracy i zasygnalizuje dźwiękowo i świetlnie błąd. Zapobiega to powstawaniu defektów. Poka-Yoke jest elementem Jidoka (automatyka z czynnikiem ludzkim), jednego z głównych filarów TPS (Toyota Production System).

\section{KAIZEN, czyli zmiana na lepsze}

Koncepcja Kaizen została oficjalnie wdrożona w Daicel Safety Systems Europe Sp. z o.o. w listopadzie 2007 r. Od tamtego momentu firma dokłada wszelkich starań, aby w sposób ciągły i systematyczny usprawniać każdy obszar funkcjonowania zgodnie z filozofią i założeniami Kaizen².
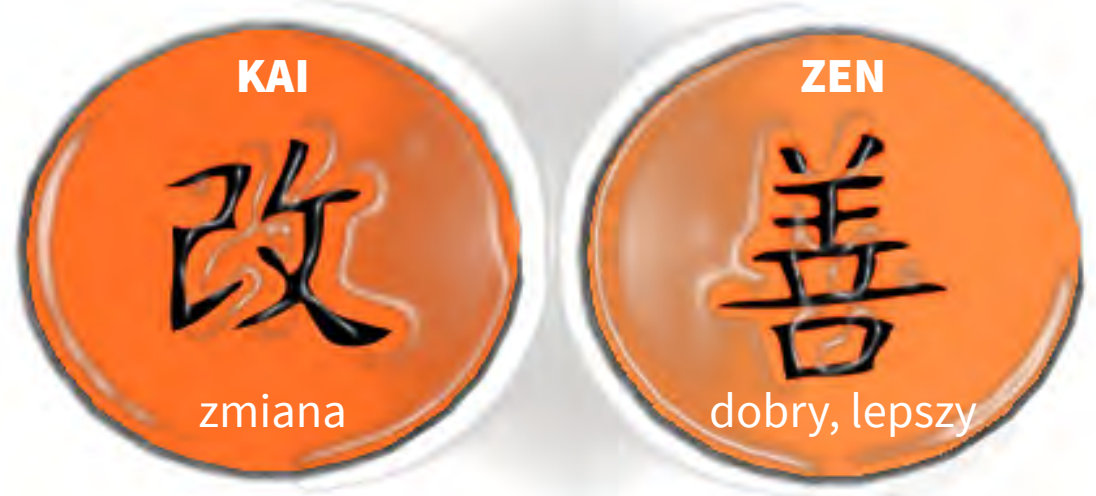

Rysunek 3. Metoda Kaizen, wizualizacja znaczenia

Źródło: opracowanie własne na podstawie http://www.daicelsse.com/kaizen,c35 [dostęp 10.05.2016].

2 http://www.daicelsse.com/ [dostęp 10.05.2016]. 


\section{Po pierwsze: 35}

- 1S. Seiri, selekcja/sortowanie - identyfikacja i usunięcie wszystkich przedmiotów, które są zbędne w miejscu pracy. Bardzo często działaniom 1S towarzyszy tzw. akcja czerwonej etykiety (red tagging), która pozwala uczynić ten krok procesem ciągłym. Polega ona na oznaczaniu przez pracowników wszystkich przedmiotów uznanych za zbędne czerwonymi etykietami, a następnie przenoszeniu ich $\mathrm{w}$ jedno wyznaczone miejsce (red tag area), gdzie podejmowana jest decyzja o ich dalszym losie. Działania 1S powinny również objąć elektroniczne nośniki informacji. Praca w toku, której zakres przekraczałby potrzeby miejsca pracy, powinna zostać odesłana do procesów odpowiedzialnych za nadwyżki.

- 2S. Seiton, systematyka - wyznaczenie miejsc przechowywania wszystkich przedmiotów, które pozostały po $1 \mathrm{~S}$ zgodnie z zasadą „miejsce dla wszystkiego i wszystko na swoim miejscu". Wyznaczając je, należy wziąć pod uwagę zasady ergonomii oraz częstotliwość korzystania z danych przedmiotów. Muszą być one również łatwe do znalezienia i odłożenia po skorzystaniu, stąd też dla oznaczenia ich lokalizacji stosuje się podpisy, etykiety, kolorowe linie, tablice cieni oraz różnego rodzaju wizualizacje.

- 3S. Seiso, sprzątanie - codzienne sprzątanie wzmacnia w pracownikach poczucie własności miejsca pracy; w firmach produkcyjnych jest ono często łączone z inspekcją, dzięki czemu możliwe jest wczesne wykrycie uszkodzeń, usterek i anomalii. Ważnym celem tego kroku jest także wyeliminowanie przyczyn źródłowych pojawiania się zanieczyszczeń w miejscu pracy³.

\section{Po drugie: eliminacja strat}

Zgodnie z filozofią Kaizen wyróżnione zostało siedem rodzajów strat, marnotrastw (z jap. Muda), które mają negatywny wpływ na funkcjonowanie zakładu i w dużej mierze przyczyniają się do generowania niepotrzebnych kosztów.

Nadprodukcja - to produkowanie w ilości przekraczajacej zamówienia klientów lub też przed zamówieniem. Rodzi to konieczność zwiększenia wydatków na powierzchnię magazynową oraz powoduje wcześniejsze zużycie surowców, jednak to ryzyko ukrytych defektów jest największe, mogą się one pojawić podczas zbyt długiego przechowywania nagromadzonych zapasów, co powoduje powstawanie dodatkowych kosztów.

3 https://pl.wikipedia.org/wiki/5S [dostęp 9.05.2016]. 


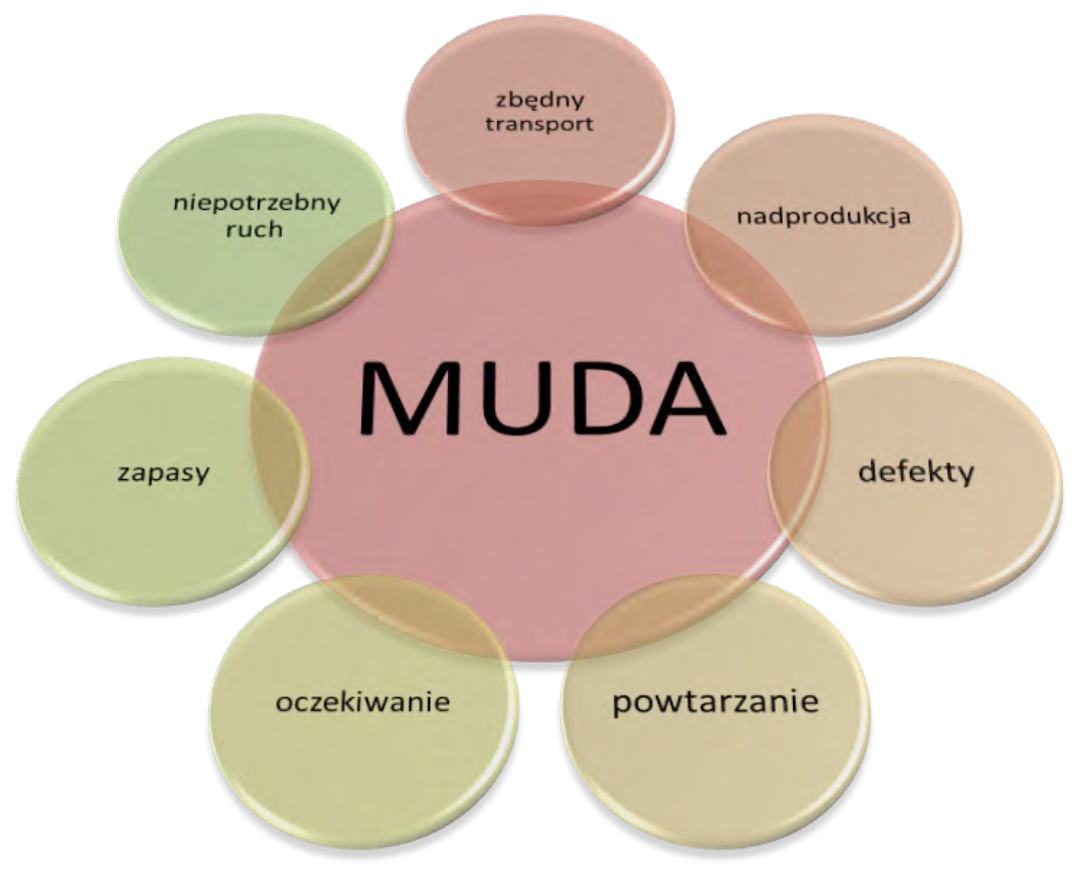

Rysunek 4. Muda (marnotrawstwa) - elementy składowe

Źródło: opracowanie własne na podstawie https://centrum.jakosci.pl/lean,co-to-jest-muda. html [dostęp 07.05.2016].

Defekty - to produkty, które nie spełniają określonych wymagań klienta. Są konsekwencją źle zaprojektowanego procesu produkcyjnego, nieodpowiednio przeszkolonych pracowników bądź wadliwie działającego sprzętu.

Niepotrzebny ruch - to czynności, które nie mają wartości dodanej, a dodatkowo wydłużają trwanie operacji standardowej. Może być to spowodowane złym zaprojektowaniem stanowiska pracy lub niewłaściwym przeszkoleniem personelu.

Zapasy - są to zgromadzone zbyt duże ilości surowców (też: produktów, półproduktów, produktów gotowych), których nie jesteśmy w stanie zużyć. Prowadzi to do marnowania powierzchni magazynowej, powstawania dodatkowych kosztów oraz może być przyczyną powstania wad ukrytych produktu lub surowca, które mogą pojawić się podczas magazynowania zgromadzonych elementów przed wykorzystaniem ich w procesie produkcyjnym bądź oczekiwania na procesy sprzedażowe.

Zbędny transport - jest to niepotrzebne przenoszenie produktów i materiałów. Transport może spowodować wady i uszkodzenia elementów transportowanych.

Przetwarzanie - jest to wykonywanie dodatkowych operacji wynikających z np. wykorzystania nieadekwatnych technologii, niewłaściwie zaprojektowanego procesu produkcyjnego lub potrzeby wyeliminowania wykrytych wad. 
Oczekiwanie - to czas, kiedy pracownik nie może wykonywać swojej pracy z powodu np. niewłaściwego przeszkolenia, awarii urządzenia, braku komponentów do produkcji, problemów administracyjnych czy kwestii organizacyjnych.

\section{Po trzecie: propozycja usprawnień}

Każdy pracownik DSSE ma możliwość składania swoich propozycji usprawnień dowolnego obszaru funkcjonowania firmy w ramach programu „Before-After”. Polega on na opisaniu stanu obecnego oraz stanu przyszłego, czyli już usprawnionego. Większość pomysłów od razu zostaje wdrożona w życie, a te, które wymagają nakładu finansowego lub aprobaty kierownictwa, rozpatrywane są przez Komisję Kaizen, która co kwartał przyznaje nagrody zarówno za największą liczbę zgłoszonych pomysłów, jak i za najlepszy jakościowo pomysł. Program „Before-After” cieszy się wielkim zainteresowaniem wśród pracowników, którzy z dużym zaangażowaniem składają swoje propozycje poprawy.

Wykres 1 przedstawia liczbę pomysłów Before-After złożonych przez pracowników firmy w latach 2010-2014.

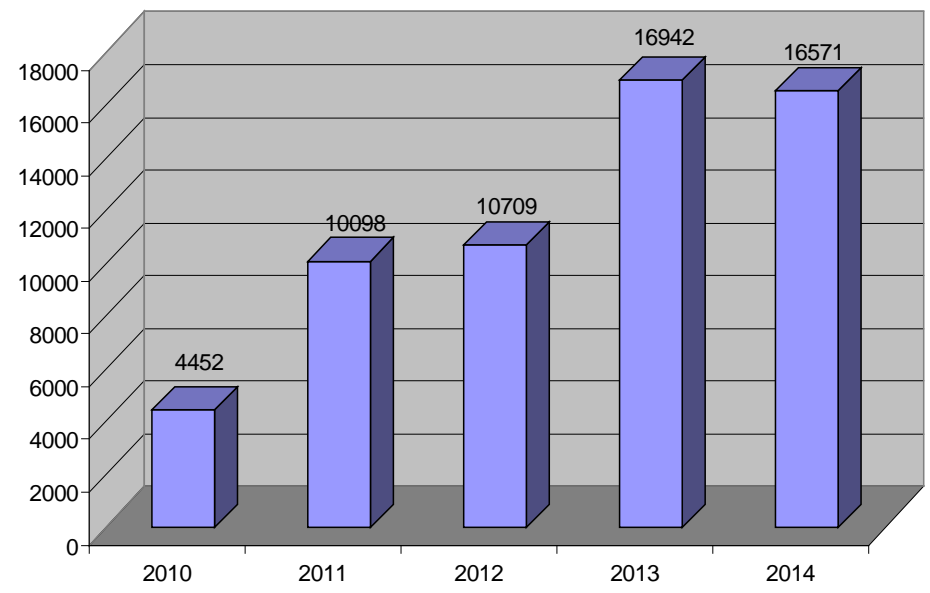

Wykres 1. Liczba pomysłów złożonych przez pracowników w ramach programu Before-After w DSSE w latach 2010-2014

Źródło: opracowanie własne na podstawie http://www.daicelsse.com/kaizen,c35 [dostęp 10.05.2016].

Dzięki propozycjom usprawnień firma DSSE zaoszczędziła w roku 2013 i pierwszym kwartale 2014 r. ponad $10 \mathrm{mln}$ PLN. 


\section{Po Czwarte: klasyfikacja SQCD}

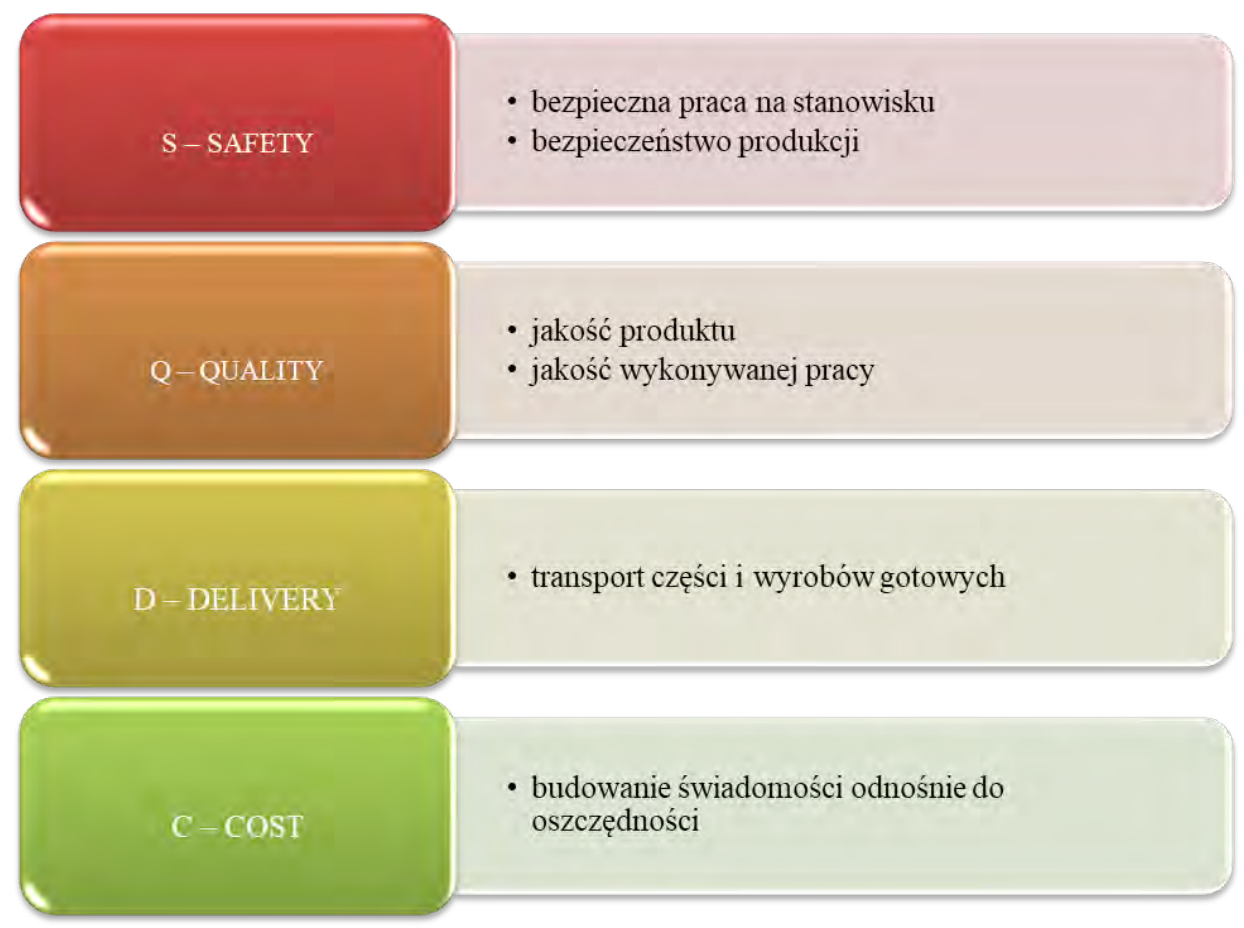

Rysunek 5. Klasyfikacja SQCD

Źródło: opracowanie własne na podstawie http://www.daicelsse.com/kaizen,c35 [dostęp 10.05.2016].

\section{Po piąte: rozwiązywanie problemów zgodnie z cyklem PDCA}

Czym jest cykl PDCA? Koło Deminga jest koncepcją z zakresu zarządzania jakością, zwaną inaczej cyklem poprawy, cyklem Deminga, cyklem PDCA (z ang. Plan, Do, Check, Act), opracowaną przez W. Edwardsa Deminga, amerykańskiego specjalistę statystyka pracującego w Japonii.

Koło Deminga zawiera chronologicznie uporządkowane działania, które są typowe dla układu sterowania ze sprzężeniem zwrotnym:

- Planowanie - P. Identyfikacja i gromadzenie informacji o organizacji w najważniejszych obszarach, gdzie poprawa będzie miała największy wpływ na 
wyniki tej organizacji. Przygotowanie szczegółowych prac podstawowych dla poprawy wszystkich działań organizacji, dezagregowanie polityki.

- Wykonanie - D. Upewnienie się, że kierownictwo rozumie cele i metodologię TQM i jest przygotowane do stosowania ich zawsze.

- Sprawdzenie - C. Przez włączenie kierownictwa i nadzoru do właściwego systemu szkolenia i komunikowania się, identyfikowanie problemów jakości i wprowadzanie ich rozwiązań, dzięki prowadzonym przez kierownictwo działaniom doskonalącym.

- Działanie - A. Rozpoczęcie nowych inicjatyw względem nowych celów i podjęcie procesu doskonalenia, pokazującego każdemu powiązania odbiorców i dostawców w łańcuchu jakości. Pozyskanie informacji o postępie i umocnienie sukcesu.

Dzięki wykorzystaniu cyklu PDCA firma DSSE jest w stanie podejść do każdego problemu w sposób systemowy:

C (Check) - sprawdzenie sytuacji obecnej, identyfikacja problemu.

A (Act) - analiza zebranych danych, rozpoznanie źródłowej przyczyny powstania problemu.

P (Plan) - zaplanowanie działań usprawniających celem rozwiązania problemu.

D (Do) - wdrożenie zaplanowanych akcji.

Nieodzownym elementem każdego cyklu PDCA jest jego ciągłe stosowanie. Po wdrożeniu działań doskonalących zawsze należy sprawdzić (Check), jaki rezultat został osiągnięty i w jakim stopniu problem został wyeliminowany.

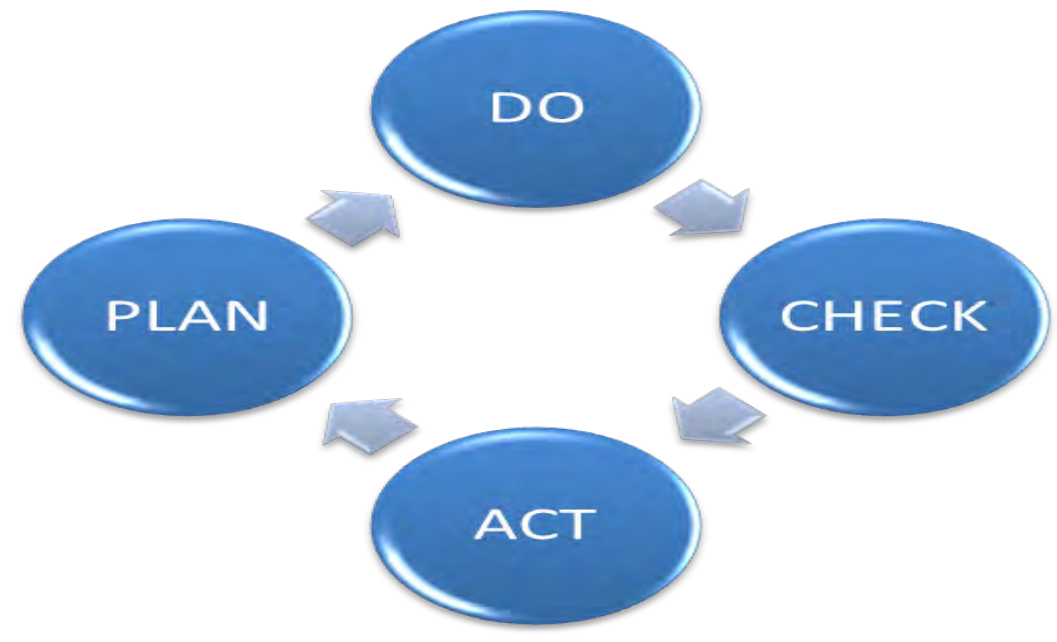

Rysunek 6. Cykl PDCA

Źródło: opracowanie własne na podstawie https://www.mindtools.com/pages/article/ newPPM_89.htm [dostęp 04.05.2016]. 


\section{Po szóste: Globalny Konkurs Kaizen}

Korporacja Daicel organizuje w Japonii coroczny Globalny Konkurs Kaizen, w którym oddziały Daicel Safety Systems prezentują swoje osiągnięcia z roku poprzedniego. Rywalizacja toczy się o tytuł zwycięzcy w dwóch kategoriach: $3 S$ oraz TPS (Toyota Production System), dodatkowo podczas konkursu odbywają się również integracyjne warsztaty Kaizen, na których pracownicy uczą się wspólnie rozwiązywać problemy oraz mają okazję do wymieniania się doświadczeniami. Nie licząc części konkursowej i warsztatów Kaizen, ważnym elementem są również warsztaty jakościowe.

Globalny Konkurs Kaizen to jeden ze stopni na drodze Daicel Safety Systems do osiągnięcia pozycji światowego lidera wśród producentów napełniaczy do poduszek powietrznych.

W roku 2013 Daicel Safety Systems w Żarowie zajęło pierwsze miejsce wśród komórek korporacji Daicel w kategorii 3S i trzecie miejsce w kategorii TPS.

\section{Ludzie}

Daicel Safety Systems Europe zatrudnia w Żarowie ponad 350 pracowników. „Ludzie" mają szczególne znaczenie, ponieważ zarządzający firmą są przekonani, że ludzie to niczym nieograniczony potencjał. Działanie zespołowe i wzajemne pogłębianie swojej wiedzy oraz doświadczenia to sposób Daicel Safety Systems na osiągnięcie przewagi rynkowej. Działając wspólnie, personel rozwija silną wolę i odwagę w podejmowaniu decyzji, a także nieustannie ewoluuje dzięki interakcjom osób o różnorodnych osobowościach.

\section{Lean a KAIZEN}

Masaaki Imai, który współpracował z Taiichi Ohno, określił sposób zarządzania wywodzący się z TPS jako KAIZEN (jap. Kai - zmiana, Zen - dobry), co oznacza zmianę na lepsze. Potrzeba ciągłego udoskonalania zakładu spowodowała wypracowanie metod, które pomagały $\mathrm{w}$ doskonaleniu procesów. Były to między innymi: 5S, PDCA, Andon, praca standaryzowana, zdefiniowanie głównych marnotrawstw w zakładzie, itp. Są to metody określane często właśnie jako narzędzia Lean. Samo wyrażenie KAIZEN wskutek użycia przez wielu stosujących Lean ule- 
gło dewaluacji i jest traktowane jako opis narzędzia polegającego na składaniu wniosków poprawy. Jednak KAIZEN, czyli ciągłe doskonalenie, należy traktować jako fundament Lean Management, bez którego zakład będzie stosował jedynie wybrane elementy „szczupłego zarządzania”.

\section{Jak w zakładzie wprowadzić ścieżkę ciągłego doskonalenia?}

Zaczynając od dogłębnego zrozumienia procesów w swoim przedsiębiorstwie i występujących w nim problemów, poprzez aktywne słuchanie pracowników oraz stosowanie narzędzi Lean, wiele przedsiębiorstw wprowadza ciągłe doskonalenie w działach swoich zakładów.

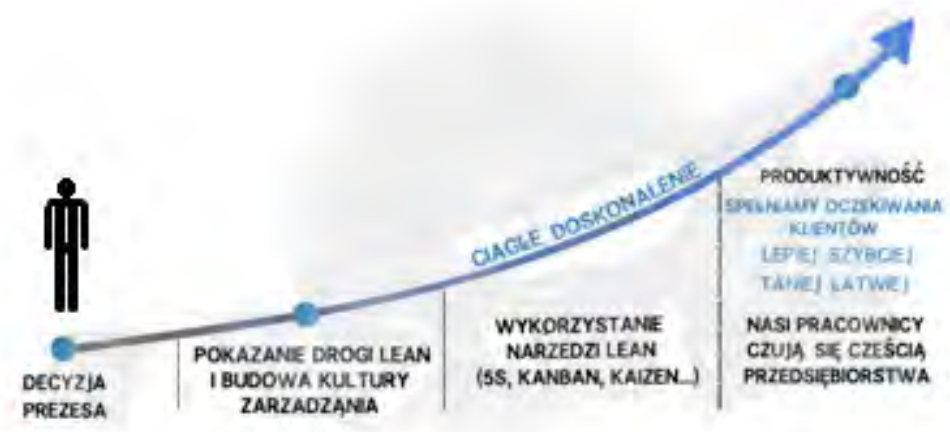

Rysunek 7. Koncepcja Lean Management w praktyce Źródło: opracowanie własne na podstawie http://www.leancenter.pl/bazawiedzy/leanmanagement [dostęp 09.05.2016].

Pomysły na udoskonalenie działania firmy DSSE to:

1. Zastosowanie kart Kanban.

2. Zastosowanie linii produkcyjnych zorganizowanych w U-gniazda.

3. Skrócenie czasów dostaw.

4. Zeszyt Kaizen.

5. Skrzynki poziomowania produkcji. 


\section{Podsumowanie}

Podsumowując, warto zadać sobie pytanie, czy firma DSSE posiada Lean? Odpowiednim pytaniem $w$ tym miejscu jest raczej pytanie o to, czy firma DSSE jest zarządzana w oparciu o ciągłe doskonalenie? Posiadanie wielu zawieszek z obrazkowymi instrukcjami i standardami pracy oraz czystość w zakładzie i organizacja stanowisk z tablicami cieni wskazują, że zarządzający przedsiębiorstwem znają narzędzia Lean i starają się wdrażać je we wszystkich działach firmy. Pracownicy produkcyjni świetnie znający 5S mogą błyszczeć przed zwiedzającym zakład, ponieważ obowiązkowo musieli się ich nauczyć. Tablice produkcyjne i codzienne krótkie spotkania z zarządzającymi, kolorowe wykresy - również mogą sprawić wrażenie, że zakład poważnie podchodzi do Lean. Ale czy tak jest na pewno?

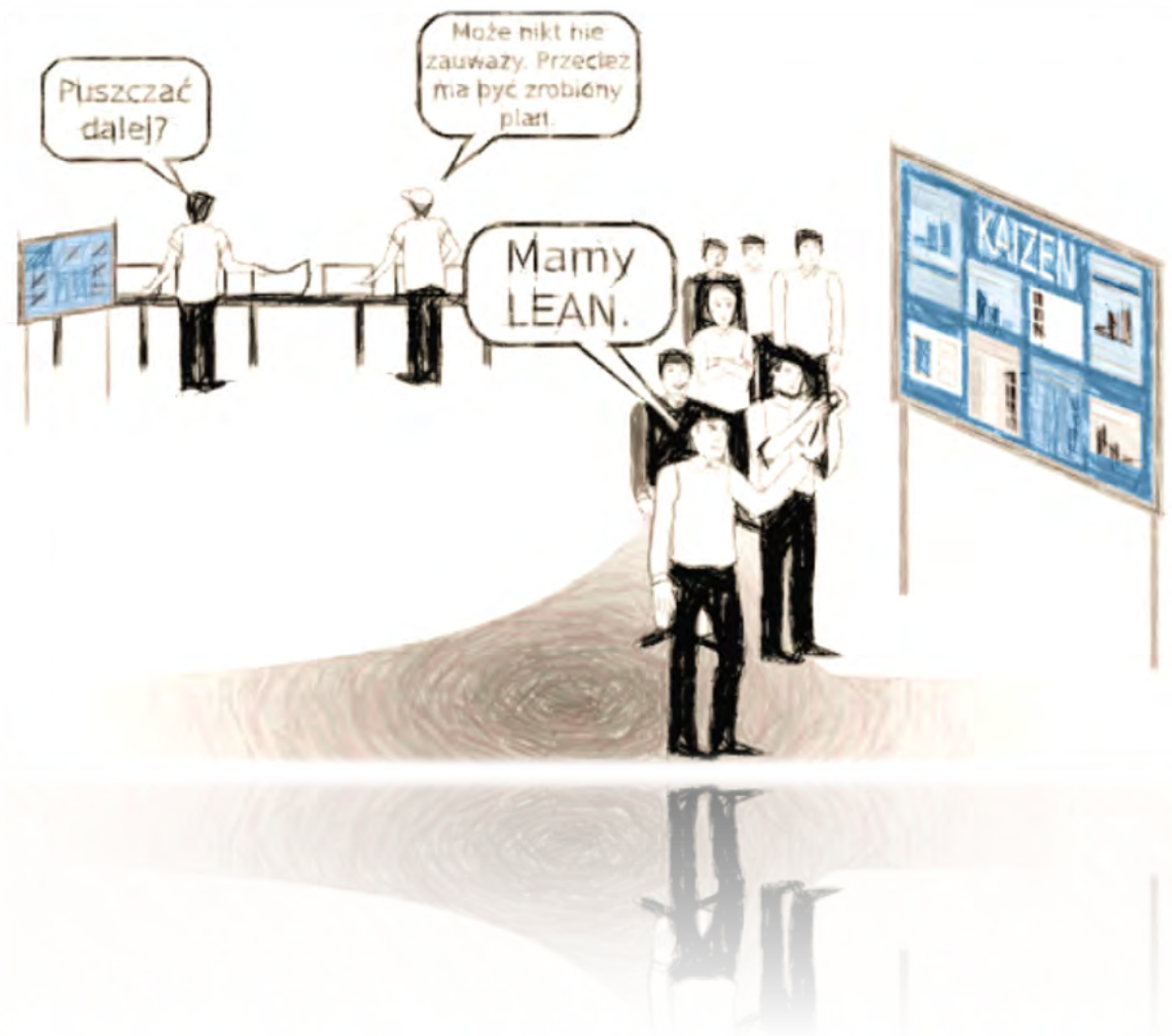

Rysunek 8. Błędne pojmowanie koncepcji Lean Management

Źródło: opracowanie własne na podstawie http://www.leancenter.pl/bazawiedzy/leanmanagement [dostęp 09.05.2016]. 
Aby odpowiedzieć na to pytanie, zastanówmy się nad tym, co robią pracownicy i jakie mają zadania. Czy każdy problem, zarówno ten mały, jak i duży, jest rozwiązywany? Czy pojawienie się wadliwego produktu na stanowisku pracy powoduje zatrzymanie całej linii produkcyjnej, tak jak to miało miejsce właśnie w Toyocie, której produkcja stała się wzorcem dla Lean Management? A może zarządzający twierdzą, że „w naszym zakładzie pozbyliśmy się już wszystkich problemów dzięki Lean"? Jeśli odpowiedź na te wszystkie pytania brzmi: tak, to warto dłużej poobserwować pracę zakładu oraz pracowników. W większości przypadków można zauważyć, że nie zawsze Lean w pełni występuje w firmie, nie jest wypracowaną przez lata kulturą zarządzania, a tylko chwilowym trendem.

\section{Bibliografia}

Detyna B., (2015), Zarządzanie jakościq w logistyce. Koncepcje, metody i narzędzia wspomagające. Ujęcie praktyczne, wyd. 2, Wyd. Uczelniane Państwowej Wyższej Szkoły Zawodowej im. Angelusa Silesiusa, Wałbrzych.

Lichtarski J., (1997), Podstawy nauki o przedsiębiorstwie, WAE, Wrocław, s. 224.

Schermerhorn J. R., Jr., (1997), Zarzq̨dzanie. Kluczowe koncepcje, wyd. 1 (wyd. 2, 2008), PWE S.A., Warszawa.

Stańczyk-Hugiert E., Perechuda K., Niemczyk J., Morawski M., (2010), Zarzq̨dzanie. Kanony i trendy, C.H. Beck, Wroctaw.

\section{Źródta internetowe}

http://www.daicelsse.com/technologia,c11 [dostęp 10.05.2016].

http://www.daicelsse.com/kaizen,c35 [dostęp 10.05.2016].

http://www.leancenter.pl/bazawiedzy/lean-management [dostęp 09.05.2016].

https://centrum.jakosci.pl/lean,co-to-jest-muda.html [dostęp 07.05.2016].

https://mfiles.pl/pl/index.php/Lean_management [dostęp 08.05.2016].

https://pl.wikipedia.org/wiki/5s [dostęp 09.05.2016].

https://www.mindtools.com/pages/article/newPPM_89.htm [dostęp 04.05.2016]. 